\title{
PENGATURAN PRINSIP TRANSFER OF UNDERTAKING PROTECTION OF EMPLOYMENT (TUPE) DALAM DUNIA KETENAGAKERJAAN INDONESIA (DIANTARA POTENSI DAN HAMBATAN)
}

\author{
Oleh : \\ Kadek Agus Sudiarawan ${ }^{1}$
}

\begin{abstract}
This research is aimed identifying the advantages of the regulation of TUPE principles, as well as inhibiting factors for outsourcing companies to apply the TUPE principles after the Decision of the Constitutional Court Number 27/PUU-IX/2011. The research was conducted by using normative-empirical method. The data of the research consisted of primary data and secondary data. All of the collected data were analyzed using qualitative method. The results of this research were presented in a descriptive analysis report. The results of the research indicated he advantages that could be obtained by workers in relation with regulation of the TUPE principles included protection of wages, welfare and working requirements, protection of workers when the company was taken over, protection of workers when there is a change of outsourcing company and regulation of the right to file a lawsuit to the industrial relations court. The inhibiting factors in the application of the TUPE principles in the outsourcing companies after the Decision of Constitutional Court were the lack of socialization and supervision of the government, various legal loopholes of discrepancies between the implementing regulation and the Decision of Constitutional Court, uncertainty severance regulation, assumptions that TUPE was a new burden which may disadvantage employers, and the lack of understanding of the workers related to their rights.
\end{abstract}

Key words: TUPE, Legal Protection, Outsourcing, FTEC.

\section{Pendahuluan}

Negara Indonesia adalah negara yang sedang berkembang. Salah satu ciri dari negara berkembang adalah pembangunan disegala bidang kehidupan. Pengembangan dunia usaha oleh para pelaku bisnis merupakan salah satu faktor yang ikut menentukan berhasilnya pembangunan. Kondisi perekonomian Indonesia yang terus berkembang semakin mendorong pemerintah

Penulis adalah Staf Pengajar (Dosen) di Fakultas Hukum Universitas Udayana, email: degust_ugm30@ yahoo.co.id. mengeluarkan berbagai kebijakan strategis dibidang perekonomian.

Secara khusus krisis finansial pada tahun 1997 telah mendorong perubahan besar terhadap sistem hukum ketenagakerjaan di Indonesia, yaitu melalui program reformasi hukum ketenagakerjaan yang pada hakekatnya menekankan pada mekanisme pasar. Hasilnya adalah diundangkannya 3 (tiga) undang-undang terkait dunia ketenagakerjaan yaitu : Undang-Undang No.21 Tahun 2000 Tentang Serikat Pekerja/ Serikat Buruh (UU SP/SB), Undang-Undang No.13 Tahun 2003 Tentang Ketenagakerjaan 
(UU Ketenagakerjaan) dan Undang-Undang No.2 Tahun 2004 Tentang Penyelesaian Perselisihan Hubungan Industrial. ${ }^{2}$

UU Ketenagakerjaan secara khusus mengatur mengenai beberapa jenis perjanjian kerja yakni meliputi : Perjanjian Kerja Waktu Tertentu (PKWT), Perjanjian Kerja Waktu Tidak Tertentu (PKWTT) dan termasuk pula outsourcing. Pengaturan PKWT dan Outsourcing dalam UU Ketenagakerjaan dapat disebut sebagai upaya untuk mewujudkan pasar kerja yang fleksibel di Indonesia.

Terkait dengan hubungan kerja outsourcing, persaingan dunia bisnis yang begitu dinamis tentunya telah memaksa perusahaan untuk berkonsentrasi pada rangkaian proses atau aktivitas penciptaan produk dan jasa yang terkait dengan kompetensi utamanya. Konsekuensi logis dari strategi ini adalah keputusan perusahaan untuk mengalihdayakan atau menyerahkan proses-proses yang bukan merupakan core competence perusahaan tersebut kepihak lain dengan sistem yang disebut sebagai oustsourcing. ${ }^{3}$

Sistem outsourcing telah memiliki landasan hukum sehingga potensi bisnis melalui sistem ini dimasa datang sangat luas dan menjanjikan. ${ }^{4}$ Pengusaha seakan berlomba-lomba untuk mendapatkan hasil dan keuntungan dengan maksimal dengan menekan pengeluaran yang minimal. Pengusaha lupa dengan sejarah yang telah terbukti gaya potong memotong ongkos

Surya Tjandra, 2007, Hukum Perburuhan, Desentralisasi, dan Rekontruksi Rezim Perburuhan Baru, TURC, Jakarta, hlm.7.

3 Richardus Eko Indrajit, 2003, Proses Bisnis Outsourcing, Grasindo, Jakarta, hlm.1.

4 Sehat Damanik, 2006, Outsourcing dan Perjanjian Kerja, DSS Publishing, Jakarta, hlm.20. ini memiliki limit tertentu, baik itu batas ekonomi maupun batas etika. ${ }^{5}$

Pelaksanaan outsourcing di Indonesia merupakan salah satu isu hangat dan menarik karena menimbukan pro kontra dimasyarakat khususnya antara kaum pengusaha dan pekerja. Gerakan penolakan yang dilakukan oleh masyarakat khususnya oleh serikat pekerja/serikat buruh terhadap penerapan sistem ini terus menguat. Tuntutan utama yang dibawa para pekerja ialah penghapusan PKWT dan outsourcing dalam dunia ketenagakerjaan Indonesia.

Langkah penting yang dilakukan pekerja untuk merespon permasalahan ini yaitu dengan mengajukan judicial riview kepada Mahkamah Konstitusi (MK) yang dilakukanolehDidikSuprijadiyangbertindak atas nama Lembaga Swadaya Masyarakat Aliansi Petugas Meter Listrik Indonesia (AP2ML). Dalam Pokok permohonannya diajukan permohonan pengujian atas Pasal 59, Pasal 64, Pasal 65 dan Pasal 66 UU Ketenagakerjaan terhadap Undang-Undang Dasar Negara Republik Indonesia Tahun 1945 (UUD NRI 1945). Menurut pemohon, ketentuan tentang outsourcing dalam pasal-pasal UU Ketenagakerjaan tersebut bertentangan dengan UUD NRI 1945 yaitu bertentangan dengan Pasal 27 ayat (2) dan Pasal 28D ayat (2) UUD NRI 1945.

Untuk menghindari perusahaan melakukan eksploitasi pekerja hanya untuk keuntungan bisnis MK kemudian melalui Putusan MK No. 27/PUU-IX/2011 menentukan perlindungan dan jaminan bagi tenaga kerja outsourcing melalui 2 (dua) model yang dapat dilaksanakan yakni :

Gunarto Suhardi, 2006, Perlindungan Hukum Bagi Para Pekerja Kontrak Outsourcing, Universitas Atmaja, Jogjakarta, hlm.1. 
Pertama, dengan mensyaratkan agar perjanjian kerja antara pekerja/buruh dengan perusahaan yang melaksanakan ousourcing tidak berbentukPKWT, melainkan berbentuk PKWTT.

Kedua, menerapkan prinsip pengalihan perlindungan bagi pekerja atau buruh atau Prinsip Transfer of Undertaking Protection of Employment (TUPE) yang bekerja pada perusahaan yang melaksanakan pekerjaan outsourcing melalui PKWT.

Prinsip TUPE merupakan prinsip yang sudah lama diterapkan negara-negara maju dan ditujukan untuk melindungi hak-hak pekerja dalam situasi perpindahan sehingga memungkinkan pekerja untuk menikmati persyaratan yang sama. Kewajiban perusahaan outsourcing yang baru untuk melanjutkan kontrak kerja yang telah ada sebelumnya ditentukan dalam Putusan MK.

Pelaksanaan Putusan MK No.27/PUUIX/2011 terbukti belum sepenuhnya mampu memberi jawaban untuk menyelesaikan permasalahan ini. Dilapangan ditemukan fakta bahwa hingga hari ini perusahaanperusahaan outsourcing masih belum banyak yang menerapkan prinsip TUPE dalam pelaksanaan outsourcing berdasarkan PKWT. Alasan tidak terlaksananya prinsip ini ialah masih ditemukan kendala sebagai faktor penghambat ditengah berbagai potensi yang bisa didapat dalam penerapan prinsip ini dalam dunia ketenagakerjaan Indonesia.

Berangkat dari latar belakang tersebut diatas maka peneliti tertarik untuk melakukan penelitian hukum dalam bidang hukum ketenagakerjaan Indonesia untuk berusaha menemukan potensi (keuntungankeuntungan) yang dapat diperoleh pekerja dengan pengaturan prinsip TUPE dalam pelaksanaan outsourcing berdasarkan
PKWT pasca Putusan MK serta menemukan faktor penghambat yang menjadi kendala perusahaan outsourcing untuk menerapkan prinsip TUPE.

\section{PEMBAHASAN}

\subsection{Potensi Pengaturan Prinsip TUPE Terhadap Pekerja Pasca Putusan MK No.27/PUU-IX/2011}

Perlindungan hukum terhadap pekerja adalah salah satu hal esensial yang kemudian terus-menerus coba untuk dievaluasi dan ditingkatkan karena beberapa pengaturan seringkali menyebabkan pekerja berada pada posisi lemah. Kondisi demikian berpotensi mengakibatkan terjadinya ekploitasi dan pengurangan terhadap hak-hakyang harusnya mereka dapatkan sebagai pekerja. Hubungan sosial antara pekerja dan pengusaha dengan demikian bermuatan konflik fundamental karena bersifat sepihak dan ekploratif. ${ }^{6}$

Dalam upaya meningkatkan perlindungan hukum terhadap pekerja khususnya bagi pekerja outsourcing yang diikat atau berdasarkan PKWT. MK melalui Putusan MK No.27/PUU-IX/2011 menegaskan bahwa pengusaha dapat menerapkan sistem outsourcing dengan status PKWT sepanjang PKWT tersebut kemudian memuat klausul yang memberi jaminan perlindungan hak pekerja (TUPE).

Konsepsi dasar klausula TUPE ini memuat ketentuan bahwa hubungan kerja pekerja yang bersangkutkan akan dilanjutkan pada perusahaan berikutnya, dalam hal obyek kerjanya tetap ada. Pada kondisi obyek pekerjaan itu tetap ada sedangkan syarat pengalihan perlindungan hak tidak

Susetiawan, 2000, Konflik Sosial, Kajian Sosiologis, Hubungan Buruh, Perusahaan dan Negara di Indonesia, Pustaka Pelajar, Yogyakarta, hlm.11. 
diatur didalam PKWT, maka hubungan kerja pekerja secara otomatis berubah menjadi PKWTT. Secara teknis syarat PKWT bisa diatur pada bagian penutup perjanjian. Pada akhirnya, klausula itu berfungsi sebagai alat ukur untuk menilai bentuk hubungan kerja apakah berbentuk PKWT atau PKWTT. ${ }^{7}$

Prinsip TUPE atau prinsip pengalihan tindakan perlindungan hak pekerja, secara khusus terdapat dalam butir (3.18) pertimbangan hukum Putusan MK No.27/ PUU-IX/2011 yang menyatakan bahwa :

“...dengan menerapkan prinsip pengalihan perlindungan ketika perusahaan pemberi kerja tidak lagi memberikan pekerjaan borongan atau penyediaan jasa perlindungan ketika perusahaan pemberi kerja tidak lagi memberikan pekerjaan borongan atau penyediaan jasa pekerja kepada suatu perusahaan outsourcing lama, dan memberikan pekerjaan tersebut kepada perusahaan outsourcing yang baru, maka selama pekerjaan yang diperintahkan untuk dikerjakan masih ada dan berlanjut, perusahaan penyedia jasa baru tersebut harus melanjutkan kontrak kerja yang telah ada sebelumnya, tanpa mengubah ketentuan yang ada dalam kontrak, tanpa persetujuan pihak-pihak yang berkepentingan, kecuali perubahan untuk meningkatkan keuntungan bagi pekerja/buruh karena bertambahnya pengalaman dan masa kerjanya. Selanjutnya disebutkan pula bahwa “...para pekerja outsourcing tidak diperlakukan sebagai pekerja baru.

Juanda Pangaribuan, "Legalitas Outsourcing Pasca Putusan MK”, http://www.hukumonline.com
Masa kerja yang telah dilalui pekerja outsourcing tersebut tetap dianggap ada dan diperhitungkan, sehingga pekerja outsourcing dapat menikmati hak-hak (upah) sebagai pekerja secara layak dan proporsional". (vide Putusan MK Perkara Nomor 27/PUU-IX/2011, hal.44 dan 45).

Pertimbangan hukum diatas menunjukkan bahwa prinsip pengalihan tindakan perlindungan (TUPE) merupakan jaminan kelangsungan hubungan kerja dan syarat-syarat kerja bagi pekerja dengan penghargaan masa kerja serta penerapan ketentuan kesejahteraan yang sesuai dengan pengalaman dan masa kerja yang dilalui oleh pekerja. ${ }^{8}$ Hakekat penerapan TUPE sebagai sebuah prinsip pengalihan tindakan perlindungan hak bagi pekerja, prinsip ini menekankan konsep bahwa jika berganti perusahaan outsourcing, masa kontrak pekerja (service year) tetap sebagai masa kerja yang diperhitungkan oleh perusahaan outsourcing baru dengan dijamin kelangsungan bekerjanya dengan kompensasi yang sama.

Secara khusus klausula TUPE seharusnya mampu memberi keuntungankeuntungan secara terhadap pekerja. Terdapat dua jenis transfer yang dilindungi di bawah TUPE transfer bisnis dan perubahan penyediaan jasa. Penerapan prinsip TUPE pada perusahaan yang melaksanakan pekerjaan outsourcing menurut MK akan berkonsekuensi hukum pada hal-hal meliputi:

\footnotetext{
Umar Kasim, "Penerapan Prinsip Pengalihan Perlindungan dalam PKWT Pasca Putusan MK" http://www.hukumonline.com
} 
a. Mengenai perlindungan upah, yang melaksanakan pekerjaan outsourcing. kesejahteraan dan syarat-syarat kerja.

b. Pekerja harus tetap mendapatkan perlindungan atas hak-haknya sebagai pekerja dalam hal suatu perusahaan diambil alih oleh perusahaan lain (perusahaan diambil alih).

c. Perlindungan bagi pekerja dalam hal terjadinya pergantian perusahaan outsourcing yang baru untuk melanjutkan kontrak kerja yang telah ada sebelumnya.

d. Pekerjaoutsourcingyangdiberhentikan dengan alasan pergantian perusahaan pemberijasapekerja, dapatmengajukan gugatan berdasarkan hal tersebut kepada pengadilan hubungan industrial sebagai sengketa hak.

\subsection{Faktor Penghambat Penerapan Prinsip TUPE Dalam Pelaksanaan Outsourcing Berdasarkan PKWT}

MK dalam Putusan MK No.27/PUUIX/2011 secara khusus tetap melegalkan outsourcing dan beranggapan bahwa pelaksanaan pekerjaan melalui outsourcing bukanlah termasuk sebagai sebuah bentuk dari sistem perbudakan modern. Putusan MK hanya menerangkan konstitusionalitas dari pasal-pasal UU Ketenagakerjaaan yang mengatur dan berkaitan dengan outsourcing itu sendiri. Konsekuensi hukum bagi pemberlakuan outsourcing pasca Putusan MK adalah diisyaratkannya hubungan kerja antara pekerja dengan perusahaan yang melaksanaan pekerjaan outsourcing dengan hubungan kerja PKWTT, atau dapat dilakukan dengan PKWT dengan syarat menerapkan prinsip pengalihan tindakan perlindungan bagi pekerja/buruh (TUPE) yang bekerja yang bekerja pada perusahaan berpengaruh terhadap peningkatan ketertarikan pengusaha untuk menerapkan sistem ini dalam suatu hubungan industrial karena sistem ini dianggap memiliki potensi bisnis sangat luas dan menjanjikan dimasa mendatang. ${ }^{9}$

Pengaturan penerapan Prinsip TUPE sebagai upaya perlindungan terhadap pekerja dalam pelaksanaan outsourcing berdasarkan PKWT masih menghadapi beberapa kendala sebagai penghambat pelaksanaannya. Faktor-faktor penghambat ini mengakibatkan pengaturan prinsip ini belum dapat diberlakukan secara efektif untuk perlindungan pekerja outsourcing berdasarkan PKWT di Indonesia.

Berdasarkan temuan penelitian di lapangan, pengaturan Prinsip TUPE sebagai upaya perlindungan hukum bagi pekerja dalam pelaksanaan outsourcing berdasarkan PKWT masih belum terlaksana dengan baik. Data sekunder hasil penelitian lapangan di beberapa perusahaan outsourcing yang sesuai dengan kriteria menunjukkan bahwa masih terdapat beberapa faktor penghambat baik dari aspek pemerintah, aturan hukum, pengusaha dan pekerja yang berpengaruh secara langsung terhadap efektifitas pengaturan prinsip ini dilapangan. Beberapa perusahaan outsourcing yang dijadikan sampel dari penelitian ini meliputi : Perusahaan outsourcing A, Perusahaan outsourcing B, Perusahaan outsourcing C dan Perusahaan outsourcing D. Keempat perusahaan yang diteliti merupakan perusahaan outsourcing yang menjalankan

Sehat Damanik, Op.cit, hlm.20. 
usaha di Provinsi Daerah Istimewa Yogyakarta (DIY) dan merupakan hasil rekomendasi dari pihak Dinas Tenaga Kerja Provinsi (Disnakertrans) DIY. Penentuan wilayah didasarkan pertimbangan untuk mempersempit ruang lingkup penelitian dan dikarenakan permasalahan yang diteliti merupakan permasalahan pendukung yang sifatnya homogen dan umum sehingga berlaku di seluruh wilayah Indonesia.

Dinakertrans DIY menyatakan bahwa belum terdapat pendataan khusus yang dilakukan Disnakertrans terkait jumlah perusahaan outsourcing yang sudah atau belum melaksanakan prinsip TUPE dalam perjanjian kerja mereka. Faktor penghambat umumialahterkaitkonsepberpikir pengusaha outsourcing yang masih berpegangan bahwa resiko pelaksanaan outsourcing tersebut ialah berada ditangan perusahaan pengguna. Kondisi ini menyebabkan perusahaan outsourcing tidak mau ambil pusing untuk memenuhi segala kriteria yang disyaratkan sebagai sebuah perusahaan outsourcing.

Celah hukum lain yang seringkali dimanfaatkan oleh perusahaan outsourcing ialah terkait tidak sinkronnya pengaturan syarat-syarat penyerahan sebagian pekerjaan terhadap perusahaan lain dengan semangat awal dari Putusan MK No.27/PUU-IX/2011, Permenakertrans RI No.19 Tahun 2012 dan SE Menakertrans RI No.04/MEN/ VIII/2013. Pengaturan yang saling tumpang tindih dengan UU Ketenagakerjaan dinilai dapat dijadikan peluang bagi perusahaan outsourcing untuk melakukan pelanggaran. Ketentuan-ketentuan pengaturan yang rawan atau seringkali dimanfaatkan perusahaan outsourcing ialah terkait kewenangan asosiasi sektor usaha, pengklasifikasian pekerjaan penunjang, tidak jelasnya pengaturan mengenai pesangon pasca pengakhiran hubungan kerja, hingga tidak tegasnya sanksi dinilai akan melemahkan tingkat efektifitas dari penerapan prinsip ini dilapangan.

Permasalahan sosialisasi dipandang menjadi menjadi sulit dilakukan tanpa didukung sinkronisasi dan kejelasan pengaturan dilapangan. Kurangnya sumber daya manusia Disnakertrans dibandingkan jumlah perusahaan outsourcing yang harus diawasi juga disinyalir menjadi salah satu faktor penyebab lemahnya pengawasan oleh pemerintah.

Disisi lain penelitian yang dilakukan terhadap perusahaan dan pekerja outsourcing di lingkungan Provinsi DIY kemudian menunjukkan beberapa pandangan terkait permasalahan yang dihadapi perusahaan dalam menyikapi kewajiban pengaturan prinsip TUPE dalam pelaksanaanoutsourcing berdasarkan PKWT.

Berdasarkan hasil analisa yang dilakukan terhadap surat perjanjian kerja antara Perusahaan outsourcing A dengan pekerja yang bekerja pada perusahaan tersebut, serta wawancara langsung dengan pekerja yang bersangkutan didapat fakta bahwa :

a. Perjanjian kerja Perusahaan outsourcing A belum menerapkan prinsip TUPE sebagai prinsip pengalihan tindakan perlindungan hak pekerja. Kondisi ini dapat dilihat dari isi perjanjian yang menyatakan bahwa kontrak kerja akan berakhir apabila pihak pengguna jasa pekerja tidak memperpanjang kontrak dengan Perusahaan outsourcing.

b. Perjanjian kerja antara Perusahaan A dengan pekerja dapat digolongkan 
dalam bentuk perjanjian baku yang ditinjau dari isinya lebih banyak menguntungkan perusahaan dan terdapat kerugian pada pekerja.

c. Pada contoh perjanjian PKWT disebutkan bahwa setiap perjanjian PKWT hanya berlaku untuk 1 tahun masa kerja, dan kemudian diperpanjang secara berluang-ulang. Ketentuan tersebut menunjukkan pekerja pada Perusahaan outsourcing A berpotensi untuk menjadi pekerja dengan hubungan berdasarkan PKWT seumur hidupnya

Data penguat berupa hasil wawancara terhadap responden menunjukkan bahwa meskipun pengaturan prinsip TUPE sebagai upaya perlindungan pekerja outsourcing berdasarkan PKWT merupakan salah satu prinsip yang baik untuk melindungi pekerja namun dalam pelaksanaanya dilapangan prinsip ini belum diatur secara khusus dalam perjanjian kerja.

Permasalahan yang sering dihadapi ialah perusahaan outsourcing lama tidak bisa masuk untuk ikut melakukan intervensi terhadap kebijakan perusahaan outsourcing baru, sementara perusahaan outsourcing baru tidak berkenan menerima pekerja dari perusahaan outsourcing lama. Kondisi ini menunjukkan bahwa pengaturan prinsip TUPE dalam suatu perjanjian kerja tidak secara otomatis berlaku, melainkan tetap memerlukan kesepakatan perusahaan outsourcing baru (pemenang tender baru). ${ }^{10}$

Sementara pada perusahaan outsourcing B ditemukan bahwa kesulitan melaksanakan prinsip ini adalah tidak lain disebabkan oleh pengaturan terkait pengakhiran hubungan kerja dalam UU Ketenagakerjaan yang akan berbenturan dengan penerapan prinsip TUPE sehingga berpotensi merugikan pihak pengusaha atau perusahaan. $^{11}$

\section{Ketentuan}

Pasal

62

UU

Ketenagakerjaan mengatur bahwa apabila salah satu pihak mengakhiri hubungan kerja sebelum berakhirnya jangka waktu yang ditetapkan dalam perjanjian kerja waktu tertentu, atau berakhirnya hubungan kerja bukan karena ketentuan sebagaimana dimaksud dalam Pasal 61 ayat (1), pihak yang mengakhiri hubungan kerja diwajibkan membayar ganti rugi kepada pihak lainnya sebesar upah pekerja sampai batas waktu berakhirnya jangka waktu perjanjian kerja. Konsekuensi dari pengaturan ini ialah ketika pengambil alihan pekerja melalui prinsip TUPE dilaksanakan ketika perusahaan outsourcing lama diputus kontraknya oleh pihak pengguna, maka perusahaan outsourcing lama yang pekerjanya dialihkan ke perusahaan outsourcing baru tentu tidak dapat melepaskan diri dari kewajiban membayar pesangon atau ganti rugi kepada pekerja sebesar upah pekerja sampai batas waktu berakhirnya jangka waktu perjanjian kerja.

Pengaturan mengenai pengakhiran hubungan kerja dalam UU Ketenagakerjaan ini kemudian secara tidak langsung dapat melemahkan semangat dari aplikasi prinsip TUPE karena dirasa akan sangat merugikan bagi perusahaan outsourcing lama.

Kondisi berbeda didapat dari hasil penelitian terhadap Perusahaan outsourcing C dimana didapat fakta bahwa masih terdapat kekurangan informasi khusus terkait

10 Wawancara pada Perusahaan Outsourcing. A

11 Wawancara pada Perusahaan Outsourcing B 
pemberlakuan prinsip ini dilapangan. Pihak perusahaan mengaku belum mengetahui secara terkait pengaturan prinsip TUPE pasca Putusan MK No,27/PUU-IX/2011. Perusahaan hingga kini masih beranggapan bahwa penerapan prinsip TUPE dalam pelaksanaan outsourcing berdasarkan PKWT bukanlah sebuah keharusan. ${ }^{12}$

Hasil wawancara terakhir terhadap perusahaan outsourcing D menunjukkan fakta yang hampir mirip bahwa informasi terkait pengaturan prinsip TUPE sebagai upaya perlindungan hukum terhadap pekerja outsourcing berdasar PKWT pasca Putusan MK belum diketahui secara utuh oleh pihak perusahaan. ${ }^{13}$

Dari sisi pekerja, didapat fakta bahwa sebagian besar pekerja belumlah memahami hak-hak mereka secara khusus sesuai yang diatur dalam peraturan perundang-undangan terkait. Masalah ketidakpahaman dan keengganan untuk menuntut hak-hak mereka masih menjadi kendala utama yang dialami pekerja sehingga upaya untuk meningkatkan perlindungan hukum terhadap pekerja outsourcing sulit untuk dapat terlaksana dengan maksimal.

\section{Penutup}

Keuntungan-keuntungan yang dapat diperoleh pekerja dengan pengaturan prinsip TUPE dalam pelaksanaan outsourcing berdasarkan PKWT pasca Putusan MK No.27/PUU-IX/2011 diantaranya meliputi : Perlindungan atas upah, kesejahteraan dan syarat-syarat kerja, Perlindungan terhadap pekerja atas hak-haknya sebagai pekerja dalam hal suatu perusahaan diambil alih oleh

Wawancara pada Perusahaan Outsourcing C Wawancara pada Perusahaan Outsourcing D perusahaan lain, Perlindungan bagi pekerja dalam hal terjadinya pergantian perusahaan outsourcing yang baru untuk melanjutkan kontrak kerja yang telah ada sebelumnya serta pengaturan bahwa pekerja outsourcing yang diberhentikan dengan alasan pergantian perusahaan pemberi jasa pekerja, dapat mengajukan gugatan berdasarkan hal itu kepada pengadilan hubungan industrial sebagai sengketa hak.

Belum diterapkannya Prinsip TUPE oleh beberapa perusahaan outsourcing bukanlah sebuah peristiwa yang berdiri sendiri tetapi disebabkan oleh beberapa faktor penghambat penerapannya yakni meliputi : Dari pemerintah (Disnakertrans), belum ada upaya aktif dari Disnakertrans untuk melakukan sosialisasi dan pengawasan sehingga terdapat masih banyak perusahaan outsourcing yang belum melaksanakan prinsip TUPE dengan tetap memperkerjakan pekerja berdasarkan PKWT.

Dari ketentuan hukum yang mengatur yakni : Putusan Mahkamah Konstitusi No.27/ PUU-XI/2011, Permenakertrans RI No.19 Tahun 2012 dan SE Menakertrans RI No.04/ MEN/VIII/2013 masih menyisakan berbagai celah hukum bagi perusahaan-perusahaan outsourcing untuk melakukan pelanggaran dengan tidak menerapkan Prinsip TUPE.

Dari pengusaha, meskipun secara finansial perusahaan-perusahaan outsourcing yang diteliti mengaku memiliki kesiapan dalam menerapkan prinsip TUPE, namun secara umum pemberlakuan prinsip TUPE dianggapdapatmenambah beban perusahaan. Pengusaha mengaku tidak mengerti dan tidak mengetahui secara detail terkait pemberlakuan prinsip TUPE pasca Putusan MK. Serta dari pekerja, permasalahan terkait kurangnya informasi, ketidakpahaman dan 
keengganan untuk menuntut hak-hak karena kedudukan psikologis pekerja yang dianggap rendah masih menjadi kendala utama yang dialami pekerja dalam memperjuangkan hak mereka.

\section{DAFTAR PUSTAKA}

\section{A. Buku- Buku}

Gunarto Suhardi, 2006, Perlindungan Hukum Bagi Para Pekerja Kontrak Outsourcing, Universitas Atmaja, Jogjakarta.

Richardus Eko Indrajit, 2003, Proses Bisnis Outsourcing, Grasindo, Jakarta.

Sehat Damanik, 2006, Outsourcing dan Perjanjian Kerja, DSS Publishing, Jakarta.

Surya Tjandra, 2007, Hukum Perburuhan, Desentralisasi, dan Rekontruksi Rezim Perburuhan Baru, TURC, Jakarta.

Susetiawan, 2000, Konflik Sosial, Kajian Sosiologis, Hubungan Buruh, Perusahaan dan Negara di Indonesia, Pustaka Pelajar, Yogyakarta.

\section{B. Artikel}

Data dari internet : http://www.hukumonline. com, Penerapan Prinsip Pengalihan Perlindungan dalam PKWT Pasca Putusan MK.

Data dari internet :http://www.hukumonline. com, Legalitas Outsourcing Pasca Putusan MK.

\section{Peraturan Perundang-Undangan}

Undang-Undang Dasar Negara Republik Indonesia Tahun 1945.

Undang-Undang No.13 Tahun 2003 Tentang Ketenagakerjaan, Lembaran Negara Republik Indonesia Tahun 2003 Nomor 39.
Putusan Mahkamah Konstitusi Nomor.27/ PUU-IX/2011.

Peraturan Menteri Tenaga Kerja Dan Transmigrasi Republik Indonesia Nomor: 19 Tahun 2012 Tentang Syarat-Syarat Penyerahan Sebagian Pelaksanaan Pekerjaan Kepada Perusahaan Lain.

Surat Edaran Menteri Tenaga Kerja Dan Transmigrasi Republik Indonesia Nomor: S E.04/MEN/V III/2013

Tentang Pedoman Pelaksanaan Peraturan Menteri Tenaga Kerja Dan Transmigrasi Republik Indonesia Nomor 19 Tahun 2012 Tentang Syarat-Syarat Penyerahan Sebagian Pelaksanaan Pekerjaan Kepada Perusahaan Lain. 